\title{
Earthquake activity in Finland and the Russian North in December 1758: rare reports and their interpretation
}

\author{
Ruben E. Tatevossian ${ }^{1,}$, Tatiana N. Tatevossian ${ }^{1}$, Päivi Mäntyniemi ${ }^{2}$ \\ ${ }^{1}$ Institute of Physics of the Earth, Russian Academy of Sciences, Moscow, Russia \\ ${ }^{2}$ Institute of Seismology, University of Helsinki, Department of Geosciences and Geography, Helsinki, Finland
}

\author{
Article history \\ Received June 7, 2012; accepted July 5, 2013. \\ Subject classification: \\ Historical seismology, Historical sources, Transfrontier earthquakes, Finland, Russian North.
}

\begin{abstract}
This investigation focuses on two historical earthquakes that occurred in the border region between Finland and Russian North in December 1758. They were close together in time and their magnitudes are among the largest observed in the region. We thoroughly searched for contemporary Russian and Scandinavian documentation on earthquake activity in several libraries in Moscow, Helsinki, Stockholm and Copenhagen. We found two primary reports, one from the Russian North and the other from Finland. The context and content of the reports indicate that they are independent and related to the dates of December 17 and December 31, 1758. The first occurrence was reportedly observed in Kandalaksha, Knyazhnaya Guba, Kovda, Chernaya reka and krest Vzista, and the second in Inari, Utsjoki, and Karasjok. We compiled macroseismic maps for both earthquakes and sets of possible parametric solutions that fit the sparse information available. We identified two types of uncertainty in epicenter and magnitude determination: one that stems from the ambiguity of intensity assessment at localities and the other from the spatial distribution of the data points. If no single solution is the best, we propose that all possible solutions be included in earthquake catalogs.
\end{abstract}

\section{Introduction}

Seismic hazard assessment is mostly based on seismic history. No sophisticated computer technology is able to fully compensate for inaccurate and short seismicity records. The problem is particularly challenging when there is a scarcity of documentary information on past earthquakes.

This investigation focuses on historical earthquake activity occurring in northern Europe, in the border region between Finland and Russian North. It is not characterized by a long cultural tradition of documentation: the native people led a nomadic way of life. It has had large areas of wilderness, and permanent settlements were mainly along waterways. The various state borders in the study region throughout the centuries have shown marked differences in language, religion, and traditions, all of which pose obstacles in the study of historical earthquakes.

The seismicity rates in the study region situated in the intraplate Baltic (Fennoscandian) Shield are low in global terms: no historical earthquake of $\mathrm{M}>5.5$ is listed in available parametric catalogs (Figure 1). Earthquakes of $\mathrm{M}>4.5$ stand out from the seismicity records as the largest observed. They are particularly intriguing, when reported close together in time and space. Tatevossian et al. [2011] studied one such case, namely two earthquakes which occurred in the spring of 1626 . Detailed analysis of written documentary accounts and historical background demonstrated that no unequivocal decision could be made, using the macroseismic data available. There may actually have been only one earthquake, which was split in two.

Another earthquake pair occurring in less than a month is listed in the parametric catalog of Kondorskaya and Shebalin [1977, 1982]: an earthquake on December 6, 1758 and another on December 31, 1758, both having magnitudes above 4 (Figure 1). However, the parametric catalog of Ahjos and Uski [1992] includes only one earthquake, on December 31, 1758. Nikonov [2004] also discussed only this earthquake in the region of interest. To obtain a better insight into the earthquake activity in the Finnish-Russian border region in December 1758 , it is necessary to search for primary sources of information.

\section{Search for primary sources}

The parametric catalog of Kondorskaya and Shebalin $[1977,1982]$ gives explicit references for the earthquakes of December 6 and 31, 1758. We traced back these references (Appendix). The earthquakes of interest were listed in many seismological compilations that repeat or summarize information from earlier works; sometimes the place names differ. 


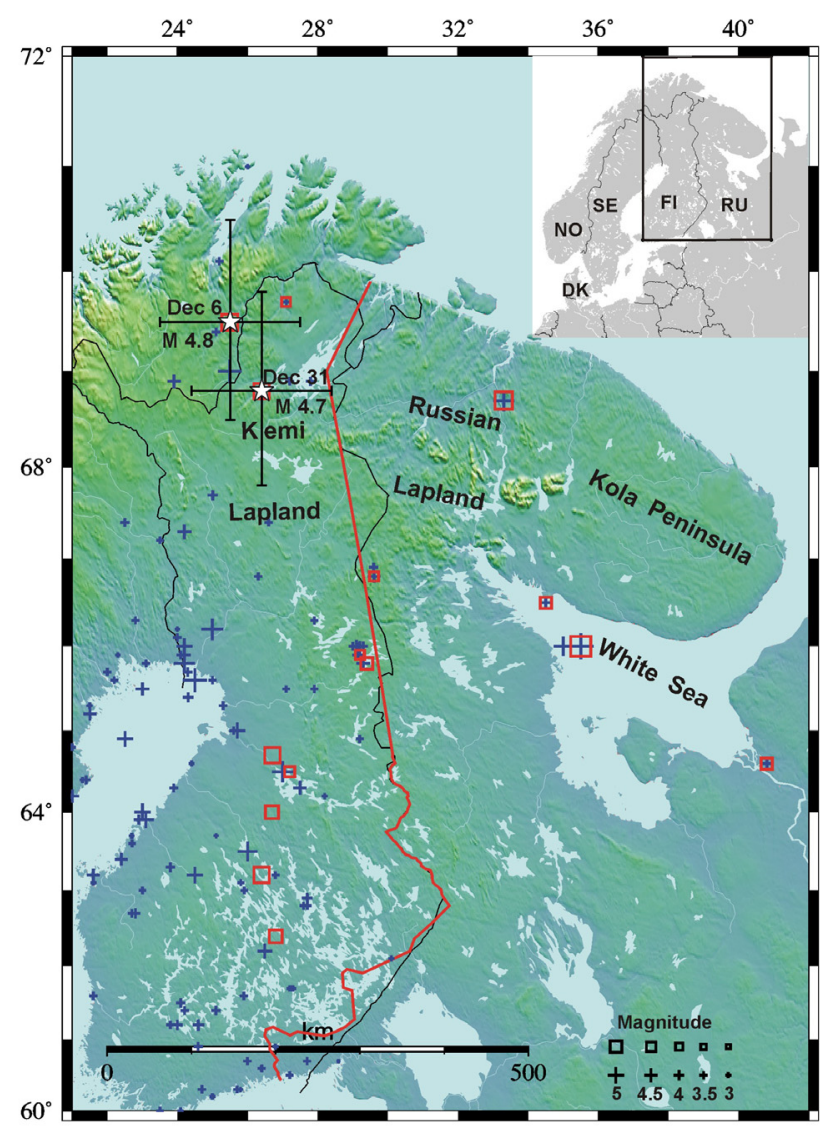

The description of the first earthquake is more confused than that of the second. The main information came from Paris, where Collection Académique [1761] was published; it does not supply any reference
Figure 1 (left). Historical seismicity in the study region from 1542 to 1899. Earthquake epicenters were taken from the parametric catalogs of Kondorskaya and Shebalin [1977, 1982] (squares) and Ahjos and Uski [1992] (crosses). Symbol size is scaled to earthquake magnitude. Only earthquakes with $\mathrm{M} \geq 3$ or $\mathrm{I}_{0} \geq 4$ are plotted. Stars are earthquake epicenters from Kondorskaya and Shebalin [1977, 1982] for Dec. $6(\mathrm{M}=4.8)$ and Dec. 31, $1758(\mathrm{M}=4.7)$; error bars correspond to location accuracy. Black lines are current state borders, while the thick red line approximates the border between the Kingdom of Sweden and Russia according to the Turku peace treaty in 1743.

for the communication. Collection Académique [1761] was used by Perrey [1845, 1846]. Renqvist [1930] reproduced the information from Perrey [1845] in French, while Mushketov and Orlov [1893] repeated the description from the Russian edition [Perrey 1846]. Thus, information from the Russian North in 1758, used before this study, was based only on a French journal not giving explicit references.

We searched for primary Russian documentation on earthquake activity in the Russian State Library in Moscow and the Slavonic Library of the National Library of Finland in Helsinki. To ensure the completeness of the search, several bibliographic indices of books and periodicals were used (Table 1). All works published in 1759, 1760,1761, and partly in 1762 and cited in the bibliographic indices - a total of 19 titles were checked (Table 2). Only one title included a primary account of an earthquake, namely the newspa-
Опыт российской библиографии или полный словарь сочинений и переводов, напечатанных на Славенском и Российском языках от начала заведения типографий до 1813 года..., собранный из достоверных источников Василием Сопиковым.

Историческое разыскание о русских повременных изданиях и сборниках за 1703-1802 гг., библиографически и в хронологическом порядке описанных А.Н. Неустроевым.

Материалы для русской библиографии. Хронологическое обозрение редких и замечательных русских книг XVIII столетия, напечатанных в России гражданским шрифтом. 1725-1800. Составил Н.В. Губерти. Вып. III.

Указатель к русским повременным изданиям и сборникам за 1703-1802 гг. и к историческому разысканию о них А.Н. Неустроева.

Русская периодическая печать (1702-1894). Справочник.

Сводный каталог русской книги гражданской печати XVIII века. 1725-1800.
Experience of Russian bibliography or complete dictionary of opuses and translations in Slavonic and Russian languages from the beginning printing up to $1813 \ldots$, collected from reliable sources by Vasiliy Sopikov.

Historical research on Russian periodicals and compilations for 1703-1802, bibliographically and chronologically described by A.N. Neustroev.

Materials for Russian bibliography. Chronological review of rare and remarkable Russian books of the 18th century printed in Russia using civil fonts. 1725-1800. Compiled by N.V. Guberti. Issue III.

Index to Russian periodicals in 1703-1802 and to the historical research done by A.N. Neustroev.

Russian periodicals (1702-1894). Handbook.

Consolidated catalog of Russian books in the 18th century. 1725-1800.
Moscow, 1950

St. Petersburg, 1813

St. Petersburg, 1874

Moscow, 1891

St. Petersburg, 1898

Moscow, 1962

Table 1. Bibliographic indices of Russian books and periodicals relevant for 1758 . 
EARTHQUAKES IN THE NORTH IN 1758

\begin{tabular}{|c|c|c|c|}
\hline Title & Publishing town & Type of publication & Result of search \\
\hline $\begin{array}{l}\text { Novi Commentarii Academie } \\
\text { Scientiarum Imperialis Petro- } \\
\text { politanae, t. (VII-XI) }\end{array}$ & Petropolis (St. Petersburg) & academic summary & $\begin{array}{l}\text { scanned from } 1763 \text { to } 1767 \text {, } \\
\text { no hits }\end{array}$ \\
\hline $\begin{array}{l}\text { Summarium Dissertationum } \\
\text { qvas continent novorum com- } \\
\text { mentariorum, t. (VII-XI) }\end{array}$ & Petropolis (St. Petersburg) & academic summary & $\begin{array}{l}\text { scanned from } 1761 \text { to } 1767 \text {, } \\
\text { no hits }\end{array}$ \\
\hline $\begin{array}{l}\text { Архангельская губерния по } \\
\text { Статистическому описанию } \\
1785 \text { года (Arkhangel'skaya gu- } \\
\text { berniya po Statisticheskomu } \\
\text { opisaniyu } 1785 \text { goda) }\end{array}$ & Arkhangelsk & statistical summary & published in 1916 , no hits \\
\hline $\begin{array}{l}\text { Декабрь } 1759 \text { год // } \\
\text { Метеорологические } \\
\text { наблюдения в Санкт Петербурге } \\
\text { в } 1758 \text { году (Dekabr’ 1759 // } \\
\text { Meteorologicheskiye } \\
\text { nablyudeniya v Sankt } \\
\text { Peeterburge v } 1758 \text { godu) }\end{array}$ & St. Petersburg & annual meteorological report & scanned through 1759, no hits \\
\hline $\begin{array}{l}\text { Ежемесячные сочинения к } \\
\text { пользе и увеселению служащие } \\
\text { (Yezhemesyachnye sochineniya } \\
\text { k pol'ze i uveseleniyu } \\
\text { sluzhashchiye) }\end{array}$ & St. Petersburg & monthly & $\begin{array}{l}\text { scanned from } 1759 \text { to } 1761 \text {, } \\
\text { no hits }\end{array}$ \\
\hline $\begin{array}{l}\text { Карманный календарь } \\
\text { (Karmanniy kalendar') }\end{array}$ & St. Petersburg & calendar & $\begin{array}{l}\text { scanned through } 1759 \text { and } \\
1760 \text {, no hits }\end{array}$ \\
\hline $\begin{array}{l}\text { Московские Ведомости } \\
\text { (Moskovskiye Vedomosti) }\end{array}$ & Moscow & national newspaper & $\begin{array}{l}\text { scanned from } 1759 \text { to } 1762 \text {; the } \\
\text { earthquake was mentioned } \\
\text { only in no. } 11,1759\end{array}$ \\
\hline $\begin{array}{l}\text { Невинное упражнение } \\
\text { (Nevinnoye uprazhneniye) }\end{array}$ & Moscow & monthly & scanned through 1763 , no hits \\
\hline $\begin{array}{l}\text { Полезное увеселение } \\
\text { (Poleznoye uveseleniye) }\end{array}$ & St. Petersburg & weekly magazine & $\begin{array}{l}\text { scanned through } 1760 \text { and } \\
1761 \text {, no hits }\end{array}$ \\
\hline $\begin{array}{l}\text { Полезное увеселение } \\
\text { (Poleznoye uveseleniye) }\end{array}$ & St. Petersburg & monthly magazine & scanned through 1762 , no hits \\
\hline $\begin{array}{l}\text { Праздное время } \\
\text { (Prazdnoye vremya) }\end{array}$ & St. Petersburg & $\begin{array}{l}\text { weekly magazine of } \\
\text { interesting happenings }\end{array}$ & scanned through 1759, no hits \\
\hline $\begin{array}{l}\text { Роспись книгам, портретам и } \\
\text { ландкартам, которые при Имп. } \\
\text { Академии наук в Санкт } \\
\text { Петербурге напечатаны и в } \\
\text { книжной палате без переплета } \\
\text { продаются. (Rospis' khigam, } \\
\text { portretam i landkartam, } \\
\text { kotorye pri Imp. Akademii } \\
\text { nauk v Sankt Peterburge } \\
\text { napechatany i v knizhnoy } \\
\text { palate bez perepleta } \\
\text { prodayutsya. 1759) }\end{array}$ & St. Petersburg & annotated index & $\begin{array}{l}\text { scanned through } 1759 \text { and } \\
1760 \text {, no hits }\end{array}$ \\
\hline $\begin{array}{l}\text { Санкт Петербургские } \\
\text { Ведомости (Sankt } \\
\text { Peterburgskiye Vedomosti) }\end{array}$ & St. Petersburg & national newspaper & $\begin{array}{l}\text { scanned from } 1759 \text { to } 1762 \text {; the } \\
\text { earthquake was mentioned } \\
\text { only in no. } 8,1759\end{array}$ \\
\hline $\begin{array}{l}\text { Свободные часы } \\
\text { (Svobodnye chasy) }\end{array}$ & St. Petersburg & monthly magazine & scanned through 1763 , no hits \\
\hline
\end{tabular}




\begin{tabular}{|c|c|c|c|}
\hline Title & Publishing town & Type of publication & Result of search \\
\hline $\begin{array}{l}\text { Собрание лучших сочинений к } \\
\text { распространению знания и к } \\
\text { произведению удовольствия, } \\
\text { или Смешанная библиотека о } \\
\text { разных физических, } \\
\text { экономических, також до } \\
\text { мануфактур и до коммерции } \\
\text { принадлежащих вещах } \\
\text { (Sobraniye luchshikh } \\
\text { sochineniy k rasprostraneniyu } \\
\text { znaniya i proizvedeniyu } \\
\text { udovol’stviya, ili smeshannaya } \\
\text { biblioteka o raznykh } \\
\text { fizicheskikh, ekonomicheskikh, } \\
\text { takozh do manufaktur i do } \\
\text { kommertsii prinadlezhashchikh } \\
\text { veshchakh) }\end{array}$ & Moscow & $\begin{array}{l}\text { magazine } \\
\text { (every three months) }\end{array}$ & $\begin{array}{l}\text { scanned through } 1762 \text {, } \\
\text { no hits }\end{array}$ \\
\hline $\begin{array}{l}\text { Содержание ученых } \\
\text { рассуждений Академии наук } \\
\text { (Soderzhaniye uchenykh } \\
\text { rassuzhdeniy Akademii nauk) }\end{array}$ & St. Petersburg & scientific journal & $\begin{array}{l}\text { scanned through } 1759 \text {, } \\
\text { no hits }\end{array}$ \\
\hline $\begin{array}{l}\text { Сочинения и переводы к пользе } \\
\text { и увеселению служащие } \\
\text { (Sochineniya i perevody k } \\
\text { pol'ze i uveseleniyu } \\
\text { sluzhashchiya) }\end{array}$ & St. Petersburg & $\begin{array}{l}\text { annual magazine of useful and } \\
\text { amazing information }\end{array}$ & $\begin{array}{l}\text { scanned from } 1758 \text { to } 1762 \text {, } \\
\text { no hits }\end{array}$ \\
\hline $\begin{array}{l}\text { СПб календарь на лето... } \\
\text { (SPb kalendar' na leto..) }\end{array}$ & St. Petersburg & $\begin{array}{l}\text { annual collection of exciting } \\
\text { events }\end{array}$ & $\begin{array}{l}\text { scanned from } 1759 \text { to } 1761 \text {, } \\
\text { no hits }\end{array}$ \\
\hline $\begin{array}{l}\text { Трудолюбивая пчела } \\
\text { (Trudolubivaya pchela) }\end{array}$ & St. Petersburg & $\begin{array}{l}\text { national monthly magazine ed- } \\
\text { ited by Sumarakov }\end{array}$ & scanned through 1759, no hits \\
\hline $\begin{array}{l}\text { Anmärckningar wid Swenske } \\
\text { Post-Tidningarne }\end{array}$ & Stockholm & $\begin{array}{l}\text { supplement to Stockholms } \\
\text { Post-Tidningar }\end{array}$ & $\begin{array}{l}\text { scanned through } 1759 \text { and } \\
1760 \text {, no hits }\end{array}$ \\
\hline Carlscronas Tidningar & Karlskrona & local newspaper & not scanned \\
\hline Den Swänska Mercurius & Stockholm & literature periodical & not scanned \\
\hline Det Swenska Biblioteket & $"$ & periodical on library issues & not scanned \\
\hline Göteborgska Magasinet & Göteborg (Gothenburg) & local newspaper & not scanned \\
\hline Hwad Nytt i Staden? & ” & $\begin{array}{l}\text { supplement to Göteborgska } \\
\text { Magasinet }\end{array}$ & not scanned \\
\hline $\begin{array}{l}\text { Kongl. Maj:ts } \\
\text { Befallningshafvandes i } \\
\text { Jönköpings län Kungörelser }\end{array}$ & Stockholm & administrative issues & not scanned \\
\hline $\begin{array}{l}\text { Kongl. Vetenskaps Academiens } \\
\text { Handlingar }\end{array}$ & , & $\begin{array}{l}\text { Proceedings of the Royal } \\
\text { Swedish Academy of Sciences }\end{array}$ & $\begin{array}{l}\text { scanned from } 1759 \text { to } 1762 \text {; } \\
1759 \text { volume, pp. } 229-232 \text { earth- } \\
\text { quake report by H. Wegelius }\end{array}$ \\
\hline Kärnan af Swea Rikes Historia & " & $\begin{array}{l}\text { history of Sweden until 1410, } \\
\text { weekly publications }\end{array}$ & not scanned \\
\hline Linköpings Stifts Tidningar & Linköping & diocese accounts & not scanned \\
\hline Lärda Tidningar & Stockholm & $\begin{array}{l}\text { scientific essays, academic dis- } \\
\text { sertations, book reviews, etc. }\end{array}$ & $\begin{array}{l}\text { scanned from } 1759 \text { to } 1761 \text {; } \\
\text { Nov } 19,1759 \text { no. } 91 \text { : summary } \\
\text { of Wegelius [1759] }\end{array}$ \\
\hline Norrköpings Weko-Tidningar & Norrköping & local newspaper & $\begin{array}{l}\text { scanned until Oct } 6,1759 \text {, } \\
\text { no hits }\end{array}$ \\
\hline
\end{tabular}




\begin{tabular}{|c|c|c|c|}
\hline Title & Publishing town & Type of publication & Result of search \\
\hline Stockholms Post-Tidningar & Stockholm & national newspaper & $\begin{array}{l}\text { scanned through } 1759 \text { and } \\
1760 ; 1759 \text { no. } 18: \text { repeat of } \\
\text { Russian account from Kan- } \\
\text { dalaksha, slightly modified }\end{array}$ \\
\hline Stockholms Stads Pris-Courant & " & buy-and-sell consumer prices & not scanned \\
\hline Stockhoms Wekoblad & “ & $\begin{array}{l}\text { agricultural issues, some scien- } \\
\text { tific writings }\end{array}$ & scanned through 1760 , no hits \\
\hline $\begin{array}{l}\text { Kiøbenhavnske Danske Post- } \\
\text { Tidender }\end{array}$ & Copenhagen & national newspaper & $\begin{array}{l}\text { scanned through 1759: Mar 9, } \\
\text { no. 20: repeat of Russian ac- } \\
\text { count from Kandalaksha, } \\
\text { slightly modified }\end{array}$ \\
\hline Nye Stats-Tidender & $"$ & $\begin{array}{l}\text { chronological overview of do- } \\
\text { mestic accounts, consumer } \\
\text { prices, etc. published monthly }\end{array}$ & scanned through 1759 , no hits \\
\hline $\begin{array}{l}\text { Copenhagener Deutsche Post- } \\
\text { Zeitungen }\end{array}$ & , & newspaper & scanned through 1759 , no hits \\
\hline $\begin{array}{l}\text { Beytrag zu Den Copenhagener } \\
\text { Deutsche Post-Zeitungen }\end{array}$ & $"$ & $\begin{array}{l}\text { supplement to Copenhageher } \\
\text { Deutsche Post-Zeitungen }\end{array}$ & $\begin{array}{l}\text { scanned through } 1759 \text { (pub- } \\
\text { lished sporadically), no hits }\end{array}$ \\
\hline $\begin{array}{l}\text { Gazette Historique et Politique } \\
\text { de Copenhague }\end{array}$ & “ & newspaper & scanned through 1759 , no hits \\
\hline
\end{tabular}

Table 2 (continued from the previous two pages). Publications in Denmark (including present-day Norway), Russia, and Sweden (including present-day Finland) scanned for reports related to the earthquakes of 1758. Literal translations of the titles can be found in the References.

per Sankt-Peterburgskiye Vedomosti [St. Petersburg Gazette] (no. 8, 1759, January 26, Tuesday). It reported an earthquake occurring in the North of Russia close to Kandalaksha on December 6, 1758. This piece of news was repeated in Moskovskiye Vedomosti [Moscow Gazette] (no. 11, 1759, February 5, Friday).

Comparison of the newspaper report from St. Petersburg with Collection Académique [1761] reveals some similar wording, which gives reason to assume that the information from Russia may have been available in France. However, the information became severely distorted in Collection Académique [1761]: Kola and Arkhangelsk were reported as localities experiencing the earthquake, while the place names given in the Russian newspaper were missing. Later compilations repeat the information rather accurately (Figure 2; Appendix).

At the time of interest, Scandinavia consisted of two kingdoms, namely Sweden including the present-day Finland (Figure 1) and Denmark including Norway [Derry 1979]. Possible accounts from Finland passed into the Swedish newspapers, and from Norway into the Danish newspapers; no newspapers were published in Finland or Norway [see Muir Wood et al. 1988]. We searched for primary Swedish and Danish documentation on earthquake activity in the National Library of Finland in Helsinki, the Royal Library of Denmark in Copenhagen and the Stadsarkivet (City Archives) in Stockholm.
A total of 16 newspapers and periodicals were issued in Sweden in 1758 and 14 the following year, according to the National Library of Sweden. The priority of the search was given to national newspapers and scientific journals, since local publications were not likely to contain news from abroad. The most important Danish newspapers were scanned as well (Table 2).

The Proceedings of the Royal Swedish Academy of Sciences contained a description of earthquake activity occurring in Utsjoki on December 31, 1758, known to Renqvist [1930]. In addition, the Swedish newspaper Stockholms Post-Tidningar (no. 18, 1759, March 1) included a slightly modified report of an earthquake occurring in the Russian North earlier the same month. The Danish newspaper Kiøbenhavnske Danske Post-Tidender repeated the Russian piece of news on March 9, 1759. The Swedish and Danish newspaper reproduced the Russian account quite accurately; in particular, the place names were given correctly, while this information was not present in later compilations (Figure 2).

\section{Analysis of sources}

\subsection{Context and content of reports}

Two earthquake reports, one from the North of Russia and the other from Swedish territory, could be classified as primary (Figure 2, Appendix). One origi- 


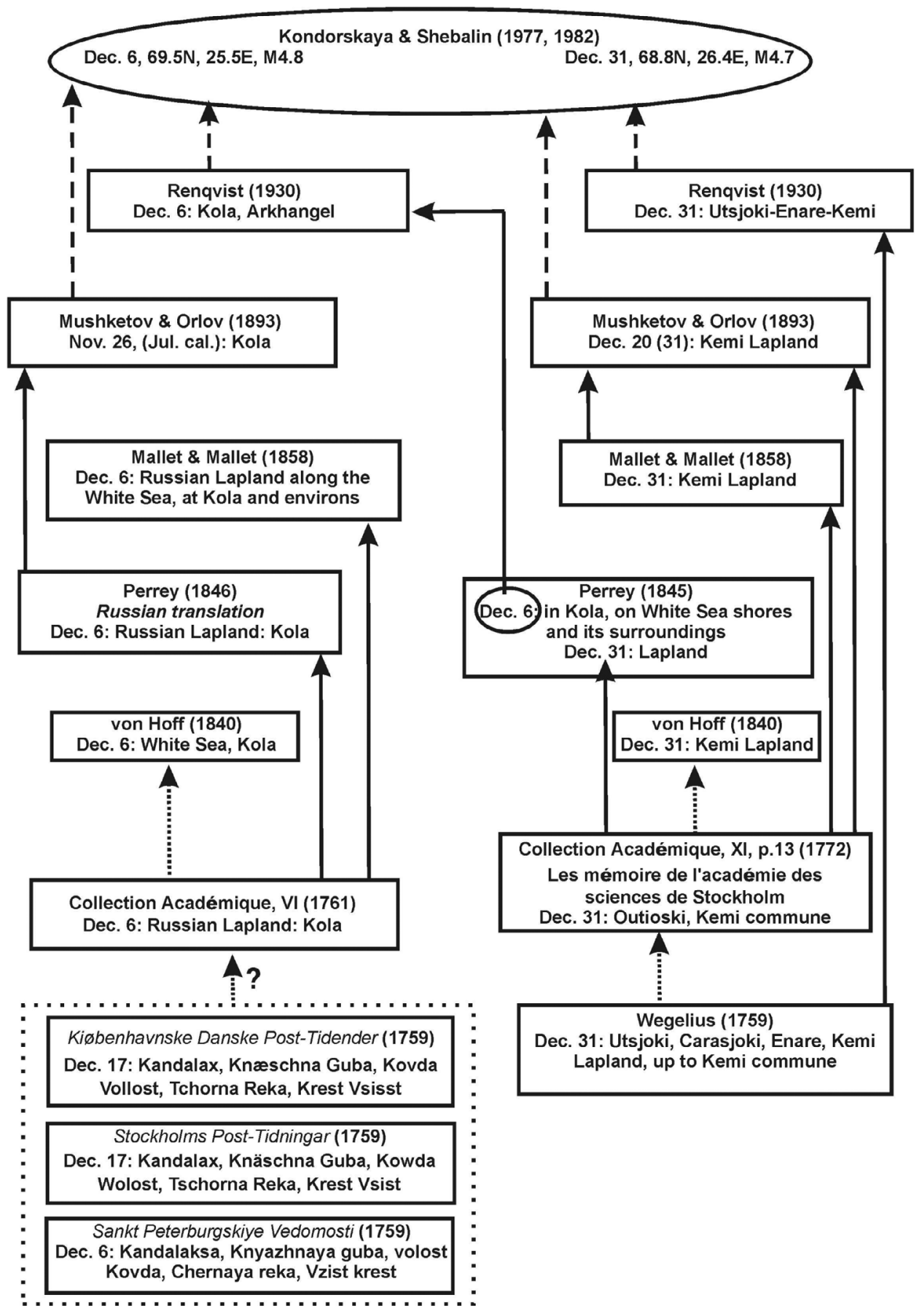

Figure 2. A flow chart of the relationships between different studies that refer to the earthquakes in Russian North and Sweden (present-day Finland) in December 1758. The dates and place names given in the studies are shown. The full original texts can be found in the Appendix.

nated from an eyewitness, the other was derived from an eyewitness' report. We cannot be sure whether the newspaper repeated the original account precisely; some distortion may have occurred at different stages, even if unintentionally. The context of the Russian report is rather unusual, but not incredible: the phenomena that occurred were observed by soldiers while they were on the road, they then reported what had happened when they reached their destination town of Arkhangelsk, from where the report passed to a newspaper published in St. Petersburg.

The Swedish author can be identified: Henrik
Wegelius (1735-1791) served as the second vicar in Utsjoki between 1758 and 1765 [Itkonen 1952]. The earthquake occurrence was included in his report of weather observations for 1758. Weather reports, besides statistics, were regarded as integral to the economic growth that began in the mid-1700s, and the clergy were taught how to make them at the Academy of Turku [Klinge 1990]. Wegelius' report [1759] was published in the Proceedings of the Royal Swedish Academy of Sciences, established in 1739 .

The reports are given in the original language in the Appendix. They were translated into English: 
- Sankt-Peterburgskiye Vedomosti, on Tuesday, January 26, 1759:

"From the town of Arkhangelsk on December 30

A soldier who came here recently from Kola fortress (ostrog) orally reported that when he was on the way on December 6 late evening a very severe storm from the northwest started, and then such a strong earthquake followed, that not were both people and livestock not able to stand on their feet but also chimneys were partly damaged and partly collapsed. Because of the severity of the shaking he had together with his comrades, also soldiers, to fall into the snow because they could not stand any longer. This earthquake lasted together with the mentioned storm for three hours, and stopped when the wind ceased. It has started at Kandalaksa [modern spelling Kandalaksha] and the same time i.e. at day 6 in the evening was felt in Knyazhnaya Guba, Kovda region [volost'], at Chernaya reka and near krest Vzista”.

\section{- Henrik Wegelius [1759]:}

"On the 31st of December last year, the weather here in Utsjoki was clear and pleasant until 4 o'clock in the afternoon, with a quiet southern wind. At 8 o'clock in the morning, the thermometer read 17 degrees, but at 10 o'clock in the afternoon it was 21 degrees below the freezing point. The barometer read 24 [Decimaltum, 7 liniers] height, all day.

At 4 o'clock in the afternoon the sky became rather misty everywhere, so that here in the vicarage the tops of the near-by hills could not be seen.

At about half past 10 in the evening, a strong underground roar began to be heard, it gradually became stronger, and seemed to approach. When it had lasted a couple of minutes, the ground began to swing, approximately like a boat in average conditions in the open sea. During that a few strong bangs were heard, close to the ground surface, which probably resulted from the fracturing of the frozen ground. The swinging lasted for 2 to 3 minutes, and the roar was still heard for a moment afterwards, until it finally came to an end.

Some 2 minutes later, the roar began to be heard again, and then a shaking followed, equally strong and long lasting as the previous one.

On the same night, at half past midnight on New Year's Day, an underground roar was still heard, however it was not as strong as the previous one and did not last that long; neither was any movement or swinging of the ground itself noticed.

During the first two tremors, and a little earlier, Northern Lights were seen on the sky (however, they were not that clear), stretching from SW to NE; it is noteworthy that all the Northern Lights seen this winter have appeared in the same direction. At 11 o'clock in the night both the Northern Lights and the mist disappeared, and the sky was entirely clear.

I tried to observe the direction of these earthquakes carefully, but could not detect it with certainty. However, I thought that the roar and tremors moved from SW to NE.

A Lapp man reported that during the earthquake he noticed some fire on the sky, resembling a flash of lightning, but however carefully I tried to observe if anything out of the usual would appear on the sky, I could not see anything.

On the following day, or the 1st of January, the ground was fractured in many places along the road passing over the ice.

That the first two tremors were rather strong can be inferred from the fact that all those who had already fallen asleep were awakened and were very frightened. People ran out and were afraid that the houses would collapse over them. The fright of the Lappish people who had gathered here by the church cannot be described. They had never before noticed any earthquakes, and had heard no talk or very little talk about them. They came to me after they escaped, and had they not heard from me any explanation about this natural phenomenon, they would probably have very peculiar thoughts about what happened.

In Karasjok in Norway, which is located some 10 miles from here [Swedish mile $=$ about $10 \mathrm{~km}$ ], the earthquakes were so discernible that the ice on one lake was totally broken. Several tremors were noticed there too during the same night.

In Inari, located some 15 miles from here towards the SSE, everybody felt the first two tremors; however, they were not as strong as here in Utsjoki. In the market place there, the chimney of the cottage of the bailiff was broken because of the swinging. The earthquake was felt not only over the entire Kemi Lapland, but also in the parish of Kemi and, maybe, even further away".

\subsection{Were two earthquakes reported?}

At that time, the Kingdom of Sweden had adopted the Gregorian calendar, while the Julian calendar was in use in Russia. The date of December 6 was given according to the Julian calendar. This was also confirmed by the newspaper from St. Petersburg; it was issued on January 26, 1758, Tuesday, a weekday that only accords with the Julian calendar. The Swedish newspaper Stockholms Post-Tidningar, in repeating the account from the Russian newspaper Sankt-Peterburgskiye Vedomosti, converted the earthquake date correctly to December 17. The same applies to the Danish newspaper Kiøbenhavnske Danske Post-Tidender. It seems that the Danish and Swedish reports were unnoticed (Figure 2, Appendix).

The dates of December 17 and December 31, 1758 


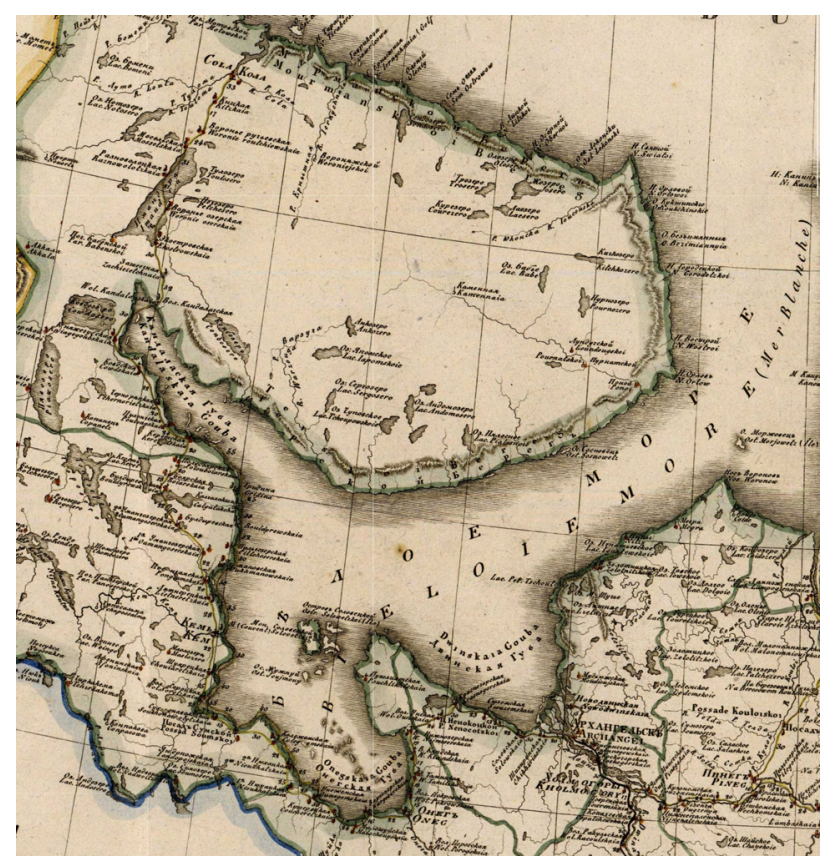

Figure 3. Map of Arkhangelsk Governatorate in 1824 (close-up). Stations on the mail delivery road and distances between them are indicated. Both winter and summer roads are shown (www.kolamap. $\mathrm{ru}$ ). Site locations are accurate to within $5 \mathrm{~km}$.

are very close together. Could there have been any confusion here, so that both reports actually referred to the same occurrence? Wegelius [1759] is considered a reliable, literate eyewitness; in addition, he wrote New Year's Day in words, so a misprint is out of the question.

The date of the occurrence in Russian North warrants some reasoning. The road between Kola and Arkhangelsk was the only one connecting these two localities and was used for mail delivery. According to Figure 3, the distance from Arkhangelsk to Kandalaksha is 890 versta $^{1}$; according to a reference book [Spravochnaya knizhka... 1850], the distance is 870 versta.

The earthquake occurred on December 6, and the report sent from Arkhangelsk is dated on December 30,1758 , both according to the Julian calendar. This leaves 23 days at the most for the soldier and his comrades to travel from Kandalaksha, where they witnessed the event, to Arkhangelsk. If there is a confusion of dates and the report was related to the second earthquake, they would have at their disposal only 9 days to reach Arkhangelsk from Kandalaksha. By no means could one cover a distance of about $950 \mathrm{~km}$ in 9 days in 1758. For comparison, according to the same reference book, the distance from Arkhangelsk to St. Petersburg is 1103 versta $(1179 \mathrm{~km})$. The message from Arkhangelsk on December 30 was published in SanktPeterburgskiye Vedomosti on January 26, i.e. more than 3 weeks later. Thus, the possibility that both primary

\footnotetext{
${ }^{1}$ Versta was a unit of distance before Russia adopted the metric system. 1 versta $=1.0668 \mathrm{~km}$.
}

reports stemmed from the same event is excluded.

The origin of the occurrences on December 17 and 31, 1758 still remains open. The first earthquake report describes a strong storm and duration of 3 hours, which is unrealistic for an earthquake, but realistic for a storm. On the other hand, it describes features typical of an earthquake: severity of shaking after the storm had begun, people and livestock having difficulty standing due to the shaking and having to fall in the snow, chimneys partly damaged and partly destroyed. The masonry parts of the timber dwellings common in the study region are the most vulnerable to earthquakes. The uncovered, complete newspaper report includes place names that extend over a distance of almost $80 \mathrm{~km}$ (from Kandalaksha to Chernaya reka). It is possible that the duration was reported incorrectly either by the soldier or by the newspaper editor. It is known even from much more recent macroseismic reports that people's estimates of earthquake duration are often not reliable. Our interpretation is that the word "storm" possibly does not refer to a meteorological phenomenon, but to the earthquake sound: first an underground roar was heard, then the ground began to shake. This interpretation is perfectly analogous with other descriptions of local earthquakes in the Baltic Shield [e.g. Mäntyniemi and Wahlström 2013]. The earthquake roar is often described as resembling thunder and lasting as long as the ground shaking. Thus, we associate a lower probability to the event of December 17 being of non-seismic origin. Wegelius' [1759] description is very detailed and includes typical earthquake features and consequences: an underground roar, shaking, an earthquake light, cracks in the ground, aftershocks, and people awakened and being frightened.

\section{Earthquake parameters}

To determine possible locations and magnitudes for the earthquakes of December 1758, use was made of the attenuation relationship given for the Baltic Shield in Kondorskaya and Shebalin [1977]:

$$
I_{i}=1.5 M-3 \log _{10} R+3
$$

where, $\mathrm{I}_{\mathrm{i}}$ is the intensity in the $\mathrm{i}^{\text {th }}$ locality at a distance $\mathrm{R}$ from the epicenter and $\mathrm{M}$ the earthquake magnitude. We assumed that attenuation was not dependent on the azimuth.

Various magnitude values were used to calculate the distance to a corresponding epicenter. Each intensity data point was encompassed by a circle having a radius corresponding to the assumed magnitude, calculated using Equation (1). The magnitude was increased stepwise, using increments of 0.1 units. Since all the distances must fit simultaneously, a possible epicenter is 

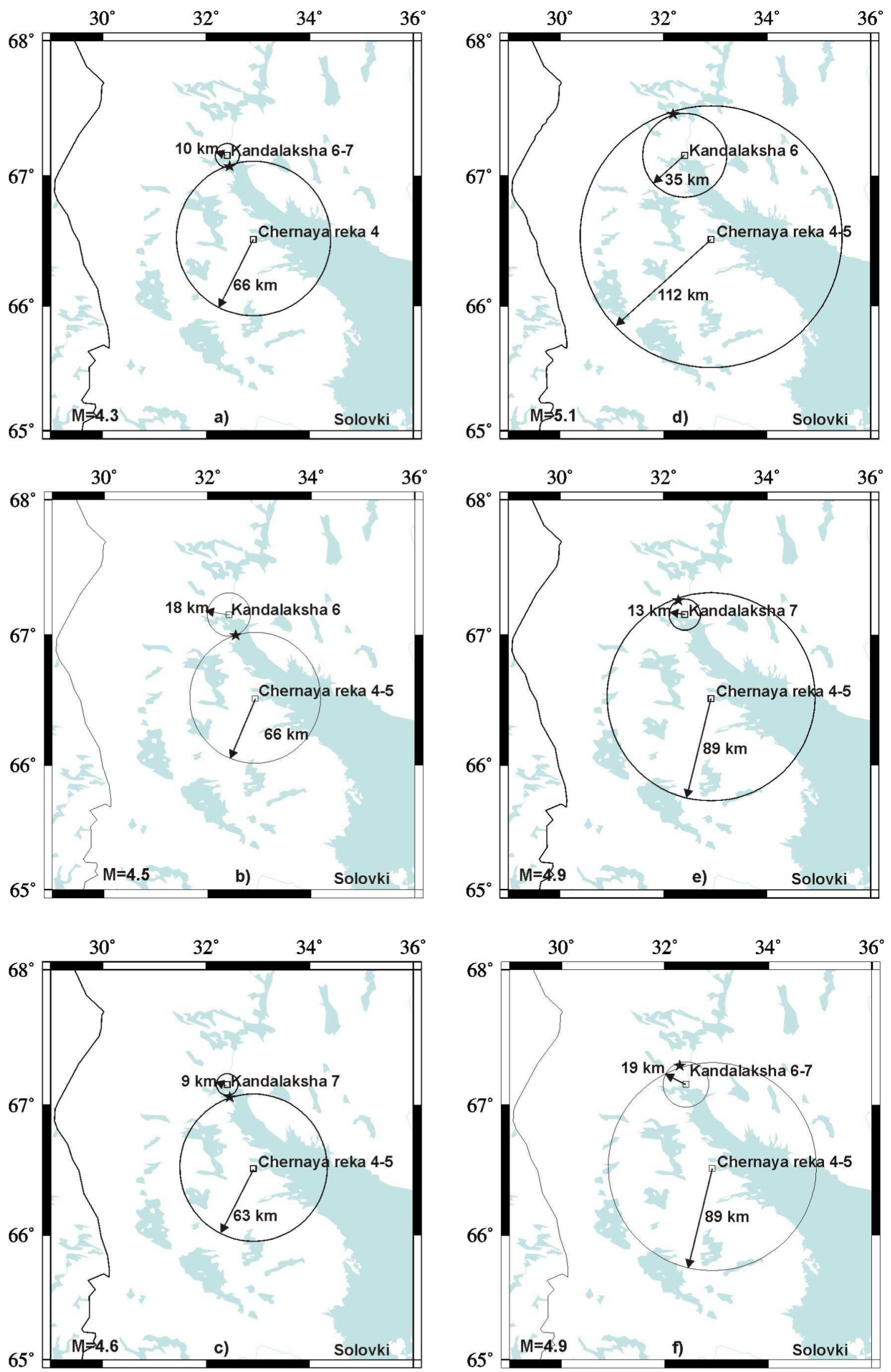

Figure 4. Stars denote possible epicenters for the earthquake of December 17, 1758 when magnitudes are assumed to be 4.3 (a), 4.5 (b), 4.6 (c), 5.1 (d), 4.9 (e), and 4.9 (f). Intensities in Kandalaksha and Chernaya reka were assessed according to the description in the newspaper SanktPeterburgskiye Vedomosti [1759] (see Table 3).

located at the point where the circles intersect. At the same time, the intersection area must have a minimum size. Alternative solutions may exist, because the circles may intersect at more than one point. 


\begin{tabular}{cccc}
\hline $\begin{array}{c}\text { Panel of } \\
\text { Figure } 4\end{array}$ & & $\begin{array}{c}\text { Chernaya } \\
\text { reka 4 }\end{array}$ & $\begin{array}{c}\text { Chernaya } \\
\text { reka 4-5 }\end{array}$ \\
\hline a) & Kandalaksha 6 & 4.3 & 4.5 \\
b) & Kandalaksha 6-7 & 4.3 & 4.6 \\
c) & Kandalaksha 7 & 4.4 & $\mathbf{4 . 6}$ \\
& & & \\
d) & Kandalaksha 6 & 4.6 & $\mathbf{5 . 1}$ \\
e) & Kandalaksha 6-7 & 4.5 & $\mathbf{4 . 9}$ \\
f) & Kandalaksha 7 & 4.5 & $\mathbf{4 . 9}$ \\
\hline
\end{tabular}

Table 3. Earthquake of December 17, 1758: magnitudes corresponding to different combinations of intensities in Kandalaksha and Chernaya reka are shown. The best-fitting values are given in a bold font. They correspond to the epicenter solutions having the smallest intersection of circles illustrated in Figure 4. The corresponding epicentral intensity $\mathrm{I}_{0}$ would be $6-7,7$, or 7-8 in cases $\mathrm{a}, \mathrm{b}$ and $\mathrm{c}$, and $\mathrm{I}_{0}$ would be $7-8$ or 8 in cases $\mathrm{d}$, e and $\mathrm{f}$.

\subsection{Earthquake of December 17, 1758}

On the way from Kola to Arkhangelsk, all travelers had to pass Kandalaksha, Knyazhnaya Guba, Kovda, Chernaya reka, and krest Vzista. The place names are given in order from the north toward the south in the newspaper account; krest Vzista was the only name we were not able to locate. It was reported that the earthquake was felt in all these localities.

All the details described are attributed to Kandalaksha. It was reported that the earthquake began near Kandalaksha; the group of soldiers could hardly have received information from there if they had already passed it. The intensity in Kandalaksha can be assessed at 6, 6-7, or 7 [EMS98, Grünthal 1998]. This was based on damage or even destruction of chimneys (suggesting an intensity of 7), but possible low-quality con- struction may have reduced it to 6, and on having difficulty standing (6-7). No details are given for other places, so intensities were not assessed at Knyazhnaya Guba and Kovda. However, for Chernaya reka, which is furthest from the Kandalaksha locality at a distance of app. $80 \mathrm{~km}$, we assumed different intensity values to limit the area of macroseismic effects reported and to be able to parameterize the earthquake. Alternative solutions for the epicenter are shown in Figure 4.

An important clerical and administrative center of documentation in the White Sea area at that time was the Solovki Monastery (Figure 4). We checked published monastery chronicles and did not find any information about ground shaking felt there in 1758. If this is taken to mean that the earthquake was not felt in Solovki, the upper limit of magnitude can be evaluated independently. This would give an upper limit of M 4.8, which agrees well with the values obtained using the intensities in Kandalaksha and Chernaya reka (Table 3).

Earthquake magnitudes of alternative solutions are presented in Table 3. In this case, the upper limit of magnitude, relying on the assumption that the earthquake was not felt at Solovki Monastery, would be 5.0, which agrees perfectly with the magnitudes obtained from the intensities in two localities. Actually, there are no grounds for preferring either of the two alternative solutions.

\subsection{Earthquake of December 31, 1758}

According to Wegelius [1759], the intensity at Utsjoki can be assigned at 5 or 5-6 [EMS98]. Higher intensity values contrast with the absence of damage, while smaller values contrast with many people being awakened and frightened. The intensities in Karasjok (Karasjoki in Finnish) and Enare (Inari) cannot be eval-
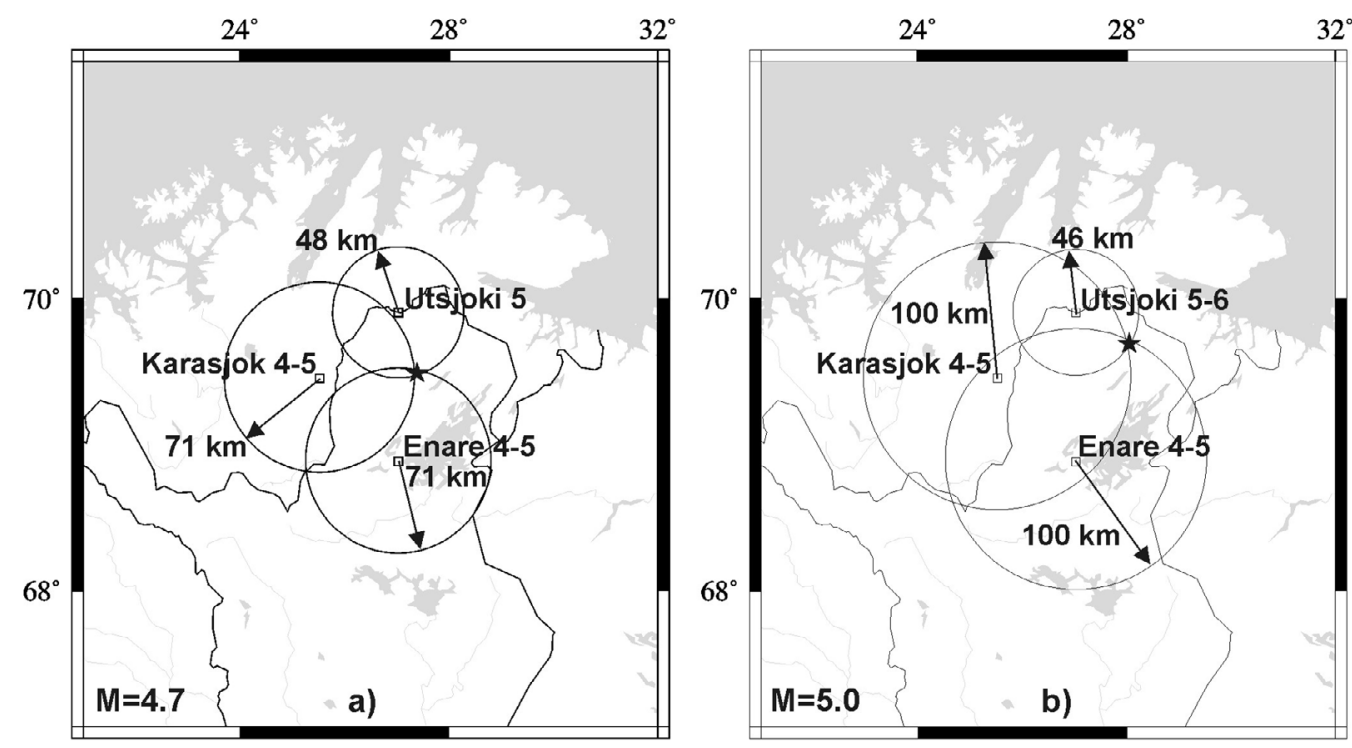

Figure 5. Stars denote possible epicenters for the earthquake of December 31, 1758 when magnitudes are assumed to be 4.7 (a) and 5.0 (b). Intensities at Utsjoki, Karasjok and Enare were assessed according to Wegelius [1759]. 
uated accurately, only that it was reported that ground shaking in these places was weaker than at Utsjoki.

Solutions corresponding to intensity values of 4-5 both in Karasjok and Enare and intensity 5 in Utsjoki (Figure 5a) or 5-6 (Figure 5b) for assumed magnitudes of 4.7 and 5.0 suggest the best fit. It follows that the intensity at the epicenter would be $\mathrm{I}_{0}=7-8$ or 8 . An independent check for the magnitude is given by the radius of perceptibility. The present-day town of Rovaniemi was chosen to represent the outskirts of 'Kemi Lapland' (meaning Finnish Lapland) where the earthquake was reportedly felt, and an intensity value of 3 was assigned to it.

For both locations (Figure 5a,b), the upper limit of magnitude is 5.1 , which agrees well with the magnitudes derived from intensities at the localities given, especially with the solution based on intensities of 5-6 in Utsjoki. Information 'felt in Kemi Lapland' also constrains the solution. An alternative intersection of circles is located toward the northeast at more than 150 $\mathrm{km}$ from Utsjoki and will require a magnitude value of $\mathrm{M}=5.7$. It contrasts with the upper limit of magnitude $(M=5.3)$ for this epicenter location (distance $470 \mathrm{~km}$ from Rovaniemi) and also the underground roar heard in Utsjoki. Therefore, it is regarded as an alternative solution with a low probability.

\section{Discussion and conclusions}

Two primary reports of earthquake activity emerged in very sparsely settled, remote northernmost Europe at the turn of 1759 . It is merely by chance that a group of soldiers experienced an earthquake on the way and that was heading toward Arkhangelsk, which was well connected to St. Petersburg where newspapers were published. Preconditions for records to appear in writing had improved only in the preceding years. A vicarage was founded in Utsjoki in 1747, making vicar Henrik Wegelius one of the very few learned persons over a large area in the far north. Interest in making systematic observations of nature was growing at that time.

The earthquake reports were distributed to other countries and appeared in many important seismological compilations (Figure 2, Appendix). However, the information was summarized, resulting in missing primary information, such as the Russian place names. Moreover, two explicitly given localities, Kola and Arkhangelsk, had nothing to do with the earthquake being felt. This supports well the principle of historians preferring sources created by eyewitnesses and contemporaries [e.g. Howell and Prevenier 2001]. In the 1758 case, the recommendation for searching for more ample data in archives and libraries [e.g. Guidoboni and Ebel 2009] did not lead to ample recoveries; instead, it is very fortuitous that as many as two separate earthquake reports exist. The chance for earthquake observations to be recorded in writing is diminished in sparsely settled regions where illiteracy is prevalent [Mäntyniemi et al. 2011].

Solutions based on the macroseismic information available for the earthquakes of December 17 and 31, 1758 are summarized in Figure 6. Differences in location and magnitude within the same alternative solution (for example, V1) directly reflect the accuracy of the solution, which follows from the uncertainty of intensity assessment in different places. The largest scatter was for $\mathrm{V} 3$ and the difference in location was $33 \mathrm{~km}$, while the smallest was for $\mathrm{V} 1$, only $9 \mathrm{~km}$. The error for magnitudes was almost the same, app. 0.2-0.3 units, for the various solutions within the same alternative.

In addition, there was uncertainty reflecting the spatial distribution of the data points, so that there was more than one combination of epicenter and magnitude that ensured the same spatial distribution of intensities. This uncertainty could not be reduced for the given spatial distribution of data points by a more accurate intensity assessment. Sometimes, additional information can help to reduce the number of alternatives. For example, when taking into account the distance of perceptibility, one can quite confidently reject alternative V4 (Figure 6).

It is important to understand clearly what contributes to the accuracy of the solution and whether the uncertainty of parametric solutions can be reduced for the dataset given. If it is not possible to objectively

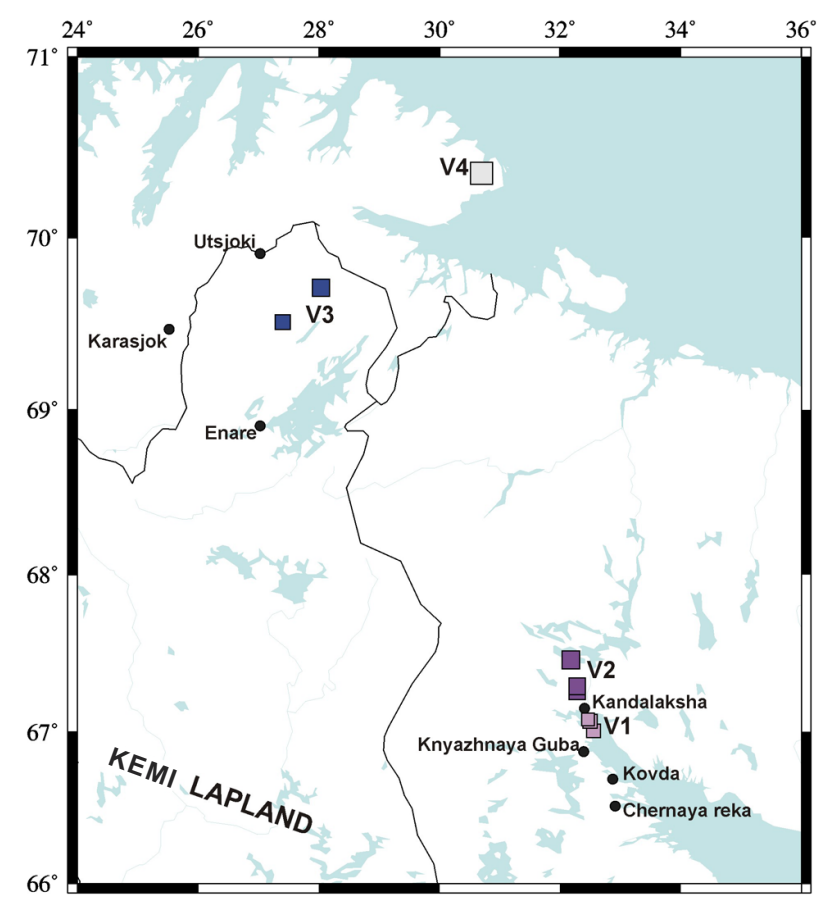

Figure 6. Squares denote possible epicenters associated with different magnitudes for the earthquakes of December 17 (V1 and V2) and 31 (V3 and V4), 1758. 
choose a single primary parametric solution, it is better to include alternative solutions in the parametric earthquake catalogs. Such an approach to cataloguing earthquake activity in the same region in 1626 was proposed by Tatevossian et al. [2011]. In this case, it is even unclear whether one or two earthquakes occurred.

In conclusion, we agree with Kondorskaya and Shebalin $[1977,1982]$ in that two separate earthquakes occurred in the Russian North and present-day Finland in December 1758. However, the date of the first earthquake was December 17 according to the Gregorian calendar; there was less confusion about the second date of December 31, 1758. Both earthquakes were supported by a primary report. However, the epicenters were changed from the previous ones to the vicinity of the Bay of Kandalaksha and northernmost Lapland. The Bay of Kandalaksha is characterized by a graben structure and associated faults mapped in e.g. Sim et al. [2011]. Instrumental recordings of microearthquakes show a pronounced seismicity trend across the FinnishRussian border toward Kandalaksha. More infrequent microearthquakes occur in the Finnish-Norwegian border region in the far north [Ahjos and Uski 1992 and updates]. The magnitudes of the two investigated earthquakes were within the range 4.3-5.0, which is rather large on the regional scale. This is quite an unusual pattern of seismicity in the region of interest.

Acknowledgements. This research was partly supported by RFBR grants 10-05-00126, 11-05-00361 and "Agreement on the Collaboration between INGV (MI-PA) and IPE, RAS”. Travel grants based on contractual bilateral cooperation between the Russian Academy of Sciences and the Academy of Finland are gratefully acknowledged. We thank the staff at the Slavonic Library of the National Library of Finland in Helsinki for their helpful assistance.

\section{References}

Primary sources

\section{Danish}

Beytrag zu Den Copenhagener Deutsche Post-Zeitungen.

Copenhageher Deutsche Post-Zeitungen.

Gazette Historique et Politique de Copenhague.

Kiøbenhavnske Danske Post-Tidender (Danish newspaper in Copenhagen).

Nye Stats-Tidender (New State newspaper).

\section{Russian}

Arkhangel'skaya guberniya po Statisticheskomu opisaniyu 1785 goda (Arkhangelsk province according to Statistical description of the year 1785), Arkhangelsk, 1916.
Dekabr' 1759 // Meteorologicheskiye nablyudeniya v Sankt Peeterburge v 1758 godu (December 1759 / / Meteorological observations in St. Petersburg in 1758), St. Petersburg.

Karmanniy kalendar' (Pocket calendar), St. Petersburg Moskovskiye Vedomosti (Moscow Gazette), Moscow.

Nevinnoye uprazhneniye (Innocent exercises), Moscow

Novi Commentarii Academie Scientiarum Imperialis Petropolitanae, t. VII-XI, St. Petersburg.

Poleznoye uveseleniye (Useful amusements), St. Petersburg.

Prazdnoye vremya (Spare time), St. Petersburg.

Rospis' khigam, portretam i landkartam, kotorye pri Imp. Akademii nauk v Sankt Peterburge napechatany i v knizhnoy palate bez perepleta prodayutsya. 1759 (List of books, portrets and landmaps published under the houspeace of Imp. Academy of Sciences in St. Petersburg published and sold without brinding in book shops), St. Petersburg.

Sankt Peterburgskiye Vedomosti (St. Petersburg Gazette), St. Petersburg.

Sobraniye luchshikh sochineniy $\mathrm{k}$ rasprostraneniyu znaniya i proizvedeniyu udovol'stviya, ili smeshannaya biblioteka o raznykh fizicheskikh, ekonomicheskikh, takozh do manufaktur i do kommertsii prinadlezhashchikh veshchakh. (Collection of the best works intended to spread knowledge and producing amusements or mixed library on various physical, economic, also related to manufacturing and commerse topics), Moscow.

Sochineniya i perevody $\mathrm{k}$ pol'ze i uveseleniyu sluzhashchiya (Works and translations for usefulness and amusements), St. Petersburg.

Soderzhaniye uchennykh rassuzhdeniy Akad. nauk (Content of scientific thoughts of Acad. Sciences), St. Petersburg.

$\mathrm{SPb}$ kalendar' na leto... (SPb calendar for year..), St. Petersburg.

Summarium Dissertationum qvas continent novorum commentariorum, t. VII-XI, St. Petersburg.

Svobodnye chasy (Spare hours), St. Petersburg.

Trudolubivaya pchela (Diligent bee), St. Petersburg.

Yezhemesyachnye sochineniya k pol'ze i uveseleniyu sluzhashchiye (Monthly opuses serving for useful and amusement), St. Petersburg.

Swedish

Anmärckningar wid Swenske Post-Tidningarne (Remarks to the Stockholm newspaper).

Carlscronas Tidningar (Karlskrona newspaper).

Den Swänska Mercurius (The Swedish Mercurius).

Det Swenska Biblioteket (The Swedish Library).

Göteborgska Magasinet (The Magazine of Gothenburg). 
Hwad Nytt i Staden? (What's new in the town?).

Kongl. Majt:s Befallningshafvandes i Jönköpings län Kungörelser (Declarations of the subjects of the royal majesty in the province of Jönköping).

Kongl. Vetenskaps Academiens Handlingar (Proceedings of the Royal Academy of Sciences).

Kärnan af Swea Rikes Historia (The nucleus of the history of the Kingdom of Sweden).

Linköpings Stifts Tidningar (Newspaper of the diocese of Linköping).

Lärda Tidningar (Learned newspaper).

Norrköpings Weko-Tidningar (Weekly newspaper of Norrköping).

Stockholms Post-Tidningar (Stockholm newspaper).

Stockholms Stads Pris-Courant (Price-newspaper of Stockholm city).

Stockholms Wekoblad (Stockholm Weekly Paper).

Wegelius, H. (1759). Berättelse Om en Jordbäfning, i Kimi Lappmark, natten emot Nyårs-dagen, innevarande år, jämte Utdrag af Meteorologiska Observationer hållne år 1758 i Utsjoki. Kungliga Vetenskaps Academins Handlingar, 1759, 229-239 (229-232).

Studies

Ahjos, T., and M. Uski (1992). Earthquakes in northern Europe in 1375-1989, Tectonophysics, 207, 1-23; updates over the Internet at www.helsinki.fi/geo/ seismo.

Collection Académique, composée de l'histoire \& de mémoires de plus célebres académies $\&$ sociétés littéraires de l'Europe (1772). Tome onzieme de la partie étrangere, contenant les mémoires de l'académie des sciences de Stockholm, Paris.

Collection Académique, composée des mémoires, actes ou journaux des plus célebres académies \& sociétés littéraires étrangère, des extraites des meilleurs ouvrage périodiques, des traités particuliers, $\&$ des piéces fugitives les plus rares (1761). Tome sixieme de la partie étrangère et le premier de la physique expérimental séparée.

Derry, T.K. (1979). A history of Scandinavia, University of Minnesota Press.

Gorshkov, G.P. (1947). O seysmichnosti vostochnoi chasti Baltiyskogo shchita (On the seismicity of the eastern part of the Baltic Shield), Trans. of the Seismological Inst. of Ac. Sc. USSR, no. 119 (in Russian).

Grünthal, G., ed. (1998). European Macroseismic Scale 1998, Cahiers du Centre Européen de Géodynamique et de Séismologie 15, Luxembourg.

Guidoboni, E., and J.E. Ebel (2009). Earthquakes and tsunamis in the past, A guide to techniques in historical seismology, Cambridge University Press.

Howell, M., and W. Prevenier (2001). From reliable sources, An introduction to historical methods, Cornell University Press.

Itkonen, T. (1952). Inari: Inarin kirkkojen ja paimenten muisto (Inari: the memory of churches and shepherds in Inari), Kotimaa, Kemi (in Finnish).

Klinge, M. (1990). Professoreita (Professors), Otava, Keuruu, 2nd ed. (in Finnish).

Kondorskaya, N.V., and N.V. Shebalin, editors-in-chief (1977). Noviy catalog sil'nykh zemletryaseniy na territorii SSSR s drevneyshikh vremen do $1975 \mathrm{~g}$. (New catalog of strong earthquakes in the U.S.S.R. from ancient times up to 1975), Moscow, Nauka, 506 pp. (in Russian).

Kondorskaya, N.V., and N.V. Shebalin, editors-in-chief (1982). New Catalog of Strong Earthquakes in the Territory of the Soviet Union from Ancient Times till 1977, Boulder, CO, USA, 608 pp.

Mallet, R., and J.W. Mallet (1858). The earthquake catalogue of the British association, with the discussion, curves, and maps, etc., Transactions of the British Association for the Advancement of Science, 1852 to 1858 , Third and Fourth Reports, London.

Mäntyniemi, P., R.E. Tatevossian and T.N. Tatevossian (2011). How to deal with sparse macroseismic data: Reflections on earthquake records and recollections in the Eastern Baltic Shield, Annals of Geophysics, 54 (3), 305-313.

Mäntyniemi, P., and R. Wahlström (2013). Macroseismic reports and intensity assessments for the earthquakes in the Bay of Bothnia area, northern Europe on 15 and 23 June 1882, Report S-57, Institute of Seismology, University of Helsinki, Finland, 88 pp.

Muir Wood, R., G. Woo and H. Bungum (1988). The history of earthquakes in the Northern North Sea, In: W.H.K. Lee, H. Meyers and K. Shimazaki (eds.), Historical seismograms and earthquakes of the world, Academic Press, 297-306.

Mushketov, I., and A. Orlov (1893). Katalog zemletryaseniy Rossiyskoy Imperii (Earthquake catalogue of Russian Empire), Zap. RGO, St. Petersburg 26, 582 pp. (in Russian).

Nikonov, A.A. (2004). Istoricheskiye zemletryaseniya (Historical earthquakes), In: N.V. Sharov (ed.), Deep structure and seismicity of the Karelian region and its margins, Petrozavodsk, 192-213 (in Russian).

Panasenko, G.D. (1969). Seysmicheskiye osobennosti severo-vostoka Baltiyskogo shchita (Seismic peculiarities of the Northeastern Baltic Shield), Leningrad, Nauka, 184 pp. (in Russian).

Perrey, M.A. (1845). Sur les tremblements de terre de la 
péninsule Scandinave, In: Voyages de la Commission scientifique du nord en Scandinavie, en Laponie, etc., Paris: A. Bertrand, Partie de la géographie physique, t.1, 64 pp.

Perrey, A. (1846). Zemletryaseniya na severe Evropy i Azii (Earthquakes in north Europe and Asia), Collection of magnetic and meteorological observations at Nikolayevskiy major geophysical observatory, St. Petersburg, no. 2 (in Russian).

Renqvist, H. (1930). Finlands jordskalv (Earthquakes in Finland), Fennia, 54, 113 pp. (in Swedish).

Sieberg, A. (1932). Erdbebengeographie, Handbuch der Geophysik, B 1.4, Berlin, 687-1005 (in German).

Sim, L.A., D.V. Zhirov and A.V. Marinin (2011). Stress and strain reconstruction for the Eastern segment of the Baltic Shield, Geodynamics and Tectonophysics, 2 (3), 219-243 (in Russian with an abstract in English).

Spravochnaya knizhka Arkhangelskoy gubernii na 1850 god. Sostavlena gubernskim statisticheskim komitetom (Reference book of Arkhangelsk province for 1850: Compiled by provincial statistical committee), Arkhangelsk, 1850 (in Russian).

Tatevossian, R.E., P. Mäntyniemi and T.N. Tatevossian (2011). On the earthquakes in the Northern Baltic Shield in the spring of 1626, Natural Hazards, 57, 133-150.

von Hoff, K.E.A. (1840). Geschichte der durch Überlieferung Nachgewiesenen Natürlichen Veränderungen der Erdoberfläche. Ein versuch. IV. Theil. Chronik der Erdbeben und Vulcan-Ausbrüche, vom Jahr 3460 vor, bis 1759 unserer Zeitrechnung. Gotha, bei Justus Perthes (in German).

Websites

National Library of Sweden: www.kb.se (accessed October 10, 2011).

Kolskiye karty (Kola map): www.kolamap.ru (accessed December 15, 2011).

\footnotetext{
${ }^{\star}$ Corresponding author: Ruben E. Tatevossian, Institute of Physics of the Earth, Russian Academy of Sciences, Moscow, Russia; email: ruben@ifz.ru. 


\section{Appendix}

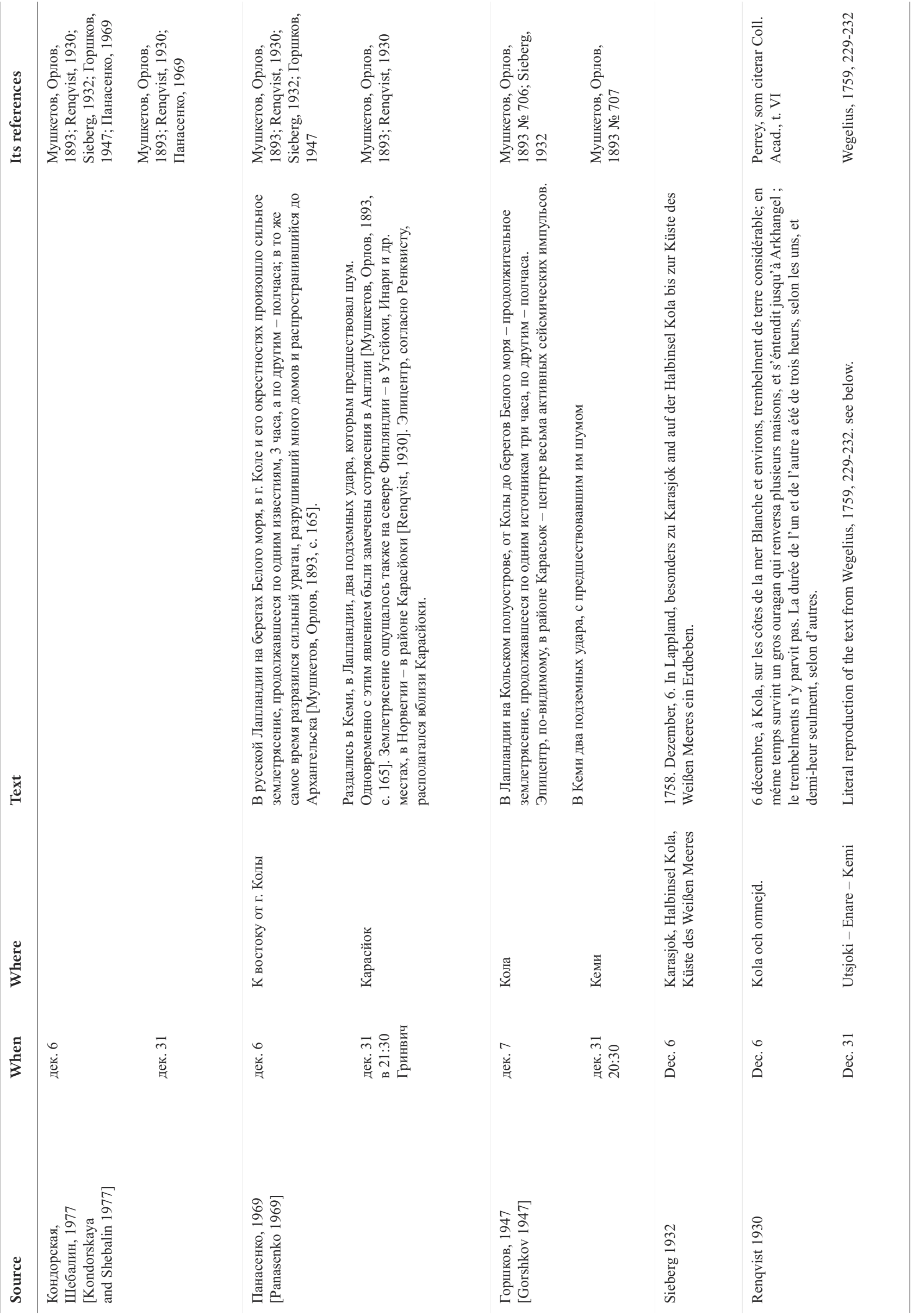


TATEVOSSIAN ET AL.

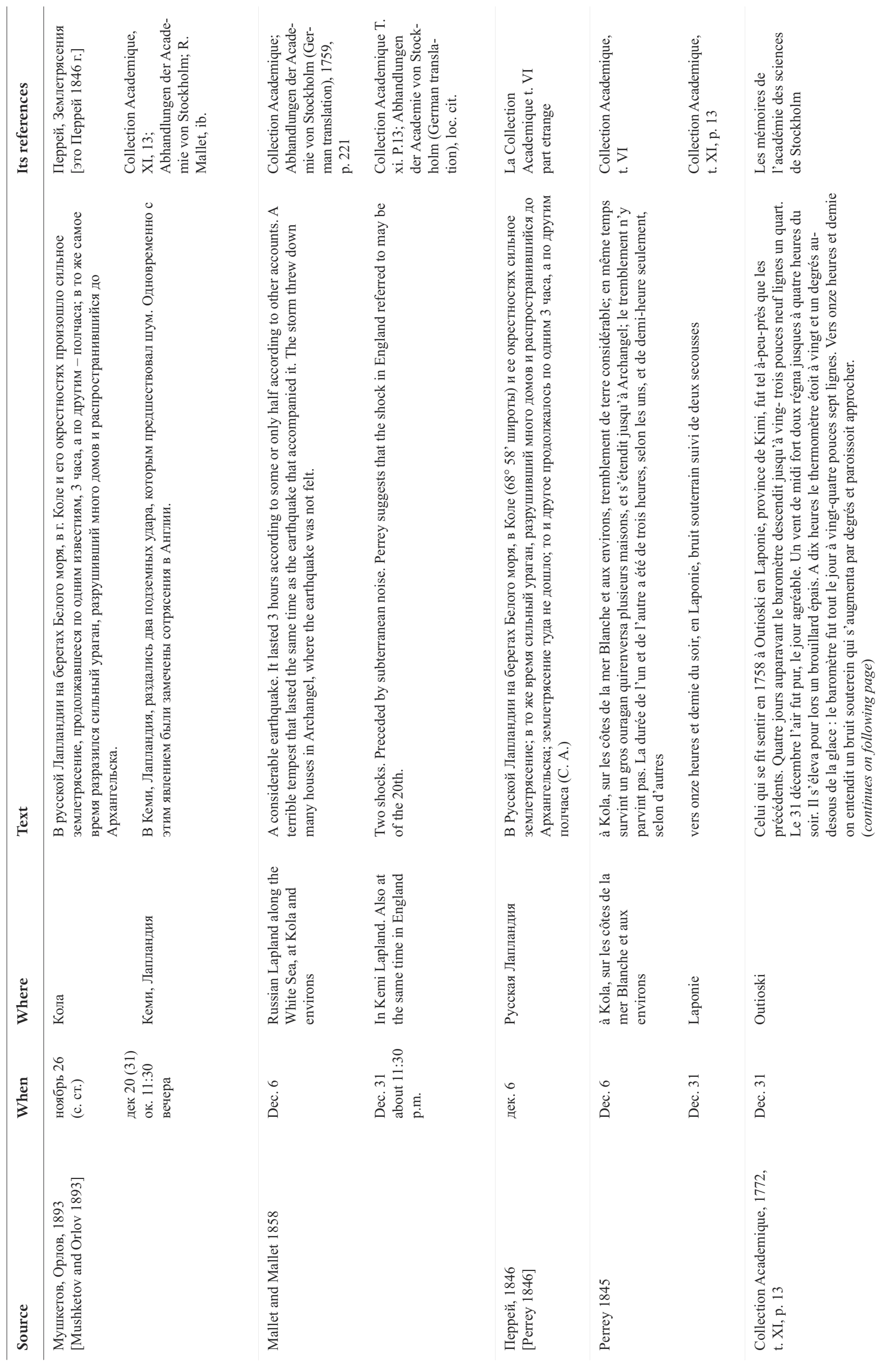


EARTHQUAKES IN THE NORTH IN 1758

离

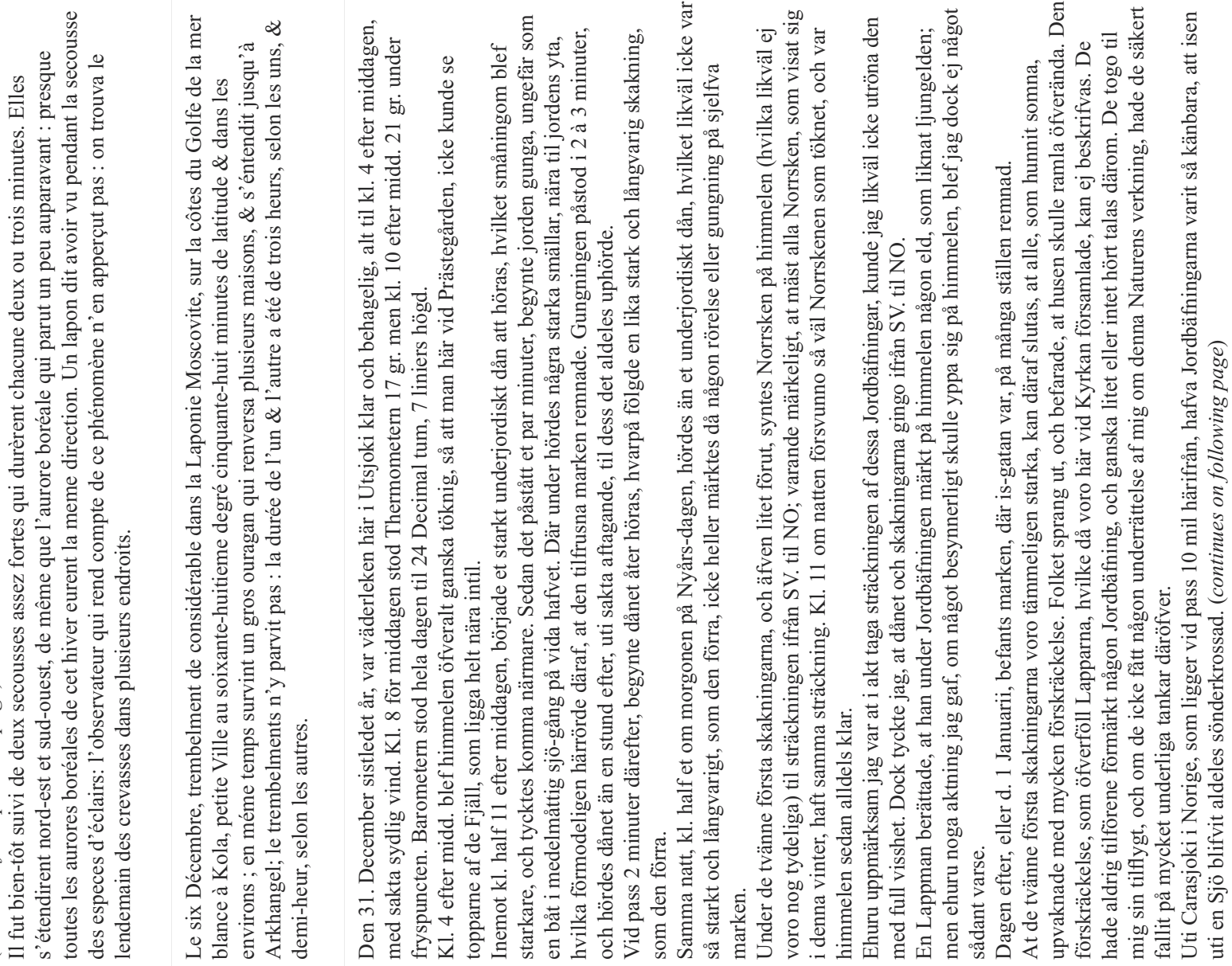

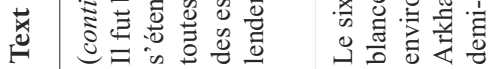

(tity

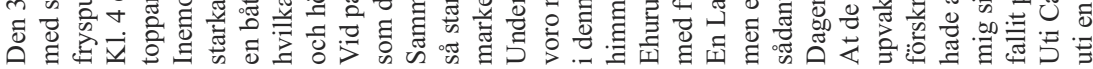

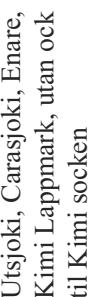

हूँ

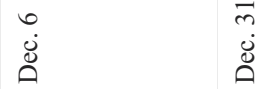

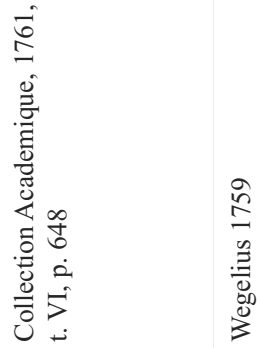


TATEVOSSIAN ET AL.

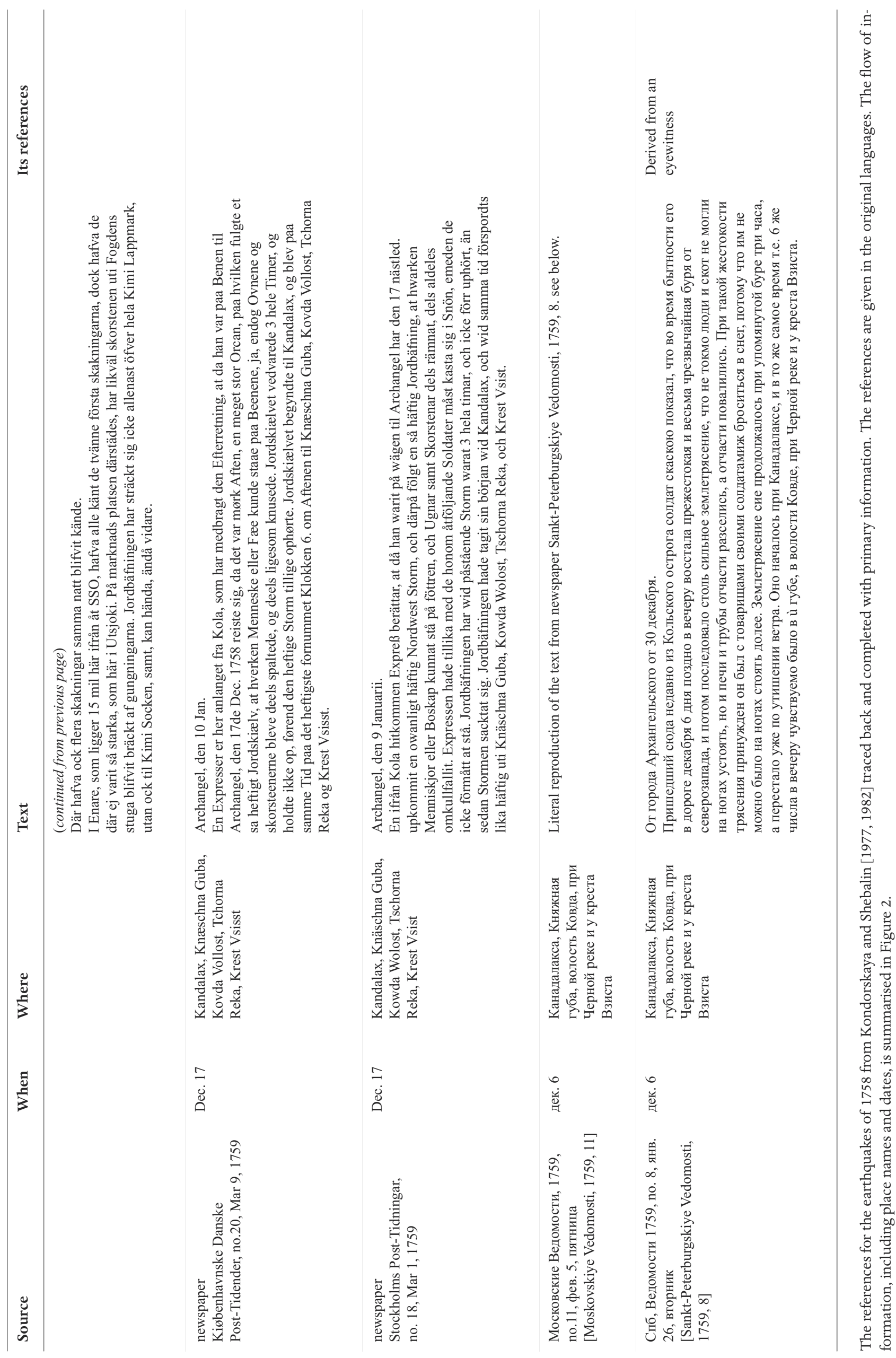

